\section{Teesside University: impact of library support provided to University students based at local partner colleges}

\author{
Sue Myer and Fran Porritt
}

\section{Introduction}

At the University of Teesside, we investigated the role of Library \& Information Services (L\&IS) in supporting University students based at 7 local partner colleges. The arrangement with partner colleges is an important one for the University (QAA, 2001, paras 25-30) and University students and staff at partner colleges are entitled to become full borrowers at the University Learning Resource Centre (LRC).

In L\&IS's Mission, Value and Aims statement (University of Teesside, 2004), one of our stated aims is: "high quality services which are well used and support the needs of students and staff". We wished to ensure that this aim was achieved for students whose experience of $\mathrm{HE}$ may be significantly different from that of students based on-campus.

\section{Application of the Impact Implementation Methodology}

What was the service trying to achieve At the outset, we wanted to answer questions such as: How clearly defined were the entitlements for partnership students? Did students based at partner colleges know that they had rights to use the University LRC? Did they find this access appropriate? How should we best communicate with them?
Therefore, our initial objectives for the research were:

- To identify the role of University L\&IS in supporting partnership students

- To increase awareness of local information resources by partnership students

- To increase collaboration with college staff to support the needs of partnership students

\section{Success criteria}

The success criteria identified for those objectives were:

\section{Objective 1}

- Agreement amongst stakeholders of role

- Role made publicly available

\section{Objective 2}

- Increased awareness displayed

- More hits on relevant web page

\section{Objective 3}

- Increased collaboration in work with partnership students

- Increased knowledge of University library facilities by college staff

- Increased knowledge of college library facilities by University Library \& Information Services staff

\section{Methods used}

The first steps in the research were to discover the baseline levels of awareness amongst library staff and students.

From staff, we decided to collect evidence of their knowledge regarding the current library service offered to partnership students. The University of Teesside's Operations Manual for Indirectly Funded Franchised Provision included an Appendix which explained the respective roles of the University LRC and the college libraries in general terms, but we were unclear how much familiarity there was with this document. We also wanted to see their attitudes towards the service, and any issues they had with the way library provision was currently organised. 
From students, we wanted to know who used the University LRC in addition to their college libraries, and what their perceptions were concerning the value of those services.

This first stage was accomplished by interviews with 7 librarians at partner colleges and with 19 University L\&IS staff, as well as by questionnaires distributed to the partnership students.

The interviews were semi-structured, as we wanted to explore the issues as fully as possible. We also asked staff to complete a questionnaire consisting of attitudes statements so that we could measure their responses to particular issues.

The questionnaires were distributed by college staff on our behalf during November-December 2003. They gave us the opportunity to collect qualitative data from off-campus students. 314 questionnaires were returned. It was difficult to measure the response rate because of the changing nature of the user population.

\section{Significant results and how they have been used}

The detailed findings of these interviews and questionnaires were summarised into a report. Some good practice was observed such as a good level of general awareness among staff, and a reasonable level of student satisfaction with library staff. However, from this research, key issues emerged. These issues included:

- Some staff uncertainty over very detailed aspects of student entitlements to particular services.

- A lack of use of the University LRC by partnership students (with only $9 \%$ of surveyed students saying they used it), based largely on an unwillingness to travel, but also on some lack of awareness about resources.

- Concern that there was a lack of awareness by students of available off-campus services even though the majority had suitable IT access ( $84 \%$ of surveyed students had home internet access)
- Desire to improve co-ordination of library provision so that both the University LRC and the college libraries displayed a consistent approach, especially over induction and information skills

- Some college librarians were concerned that they were not adequately consulted over resource needs for particular programmes

21 recommendations were made in this initial report and were circulated amongst members of L\&IS staff as well as LRC staff from the partnership colleges. Staff were asked to vote on each of the recommendations, using a Lickert scale, which allowed staff to indicate varying levels of agreement.

The results of the votes were then discussed at a Higher Education Business Partnership (HEBP) meeting of library and information professionals, which comprised senior staff from University L\&IS as well as librarians from each of the colleges. The voting mechanism proved a useful way of obtaining feedback on the recommendations, and enabled initial actions to be targeted towards proposals for which there was a clear consensus.

The next stage of the research was to act on those recommendations. A number of initiatives took place. For example:

- A factsheet for partnership students (http://www.tees.ac.uk/lis/whoweare/factsheet s/fs17.pdf) was expanded to include more detailed information on all relevant services.

- A new section of the University of Teesside L\&IS web site was created which is aimed particularly at partnership students http://www.tees.ac.uk/lis/partnership . This section includes lists of electronic resources and University L\&IS contact names for each of the programmes. Together with the factsheet, this initiative may be seen as fulfilling the success criteria for Objective 1 listed above.

- College librarians were introduced to University-funded online databases during a staff development day so that they were better prepared to provide information skills training to students at their colleges. 
- Records were kept of the numbers of inductions which were carried out during Autumn 2004 both at the college libraries and the University LRC, to see if the inductions could be better co-ordinated.

- A letter was sent out to all programme leaders at the partnership colleges encouraging them to make use of both their college libraries and the University LRC. The letter was accompanied by other information from L\&IS.

- In order to identify year-on-year usage trends, work began on collecting statistical data such as:

o usage of Athens-authenticated resources by partnership students

o number of hits on the web pages which give information about resources particularly for partnership students

An interim report was presented to a meeting of the HEBP library and information professionals in November 2004, which described the progress that had been made on each of the recommendations from the previous report.

After reading the report, members of the group were asked to consider whether or not the original objectives had been met. Positive comments were received such as "I feel we are now working 'as a team'”, "the HEBP development day was a very good idea" and "I feel able to support students in the use of databases". However, the college library staff agreed that it was too early to tell if there had been any measurable differences for students and for college teaching staff. This was not surprising: the web site was only fully introduced in July 2004 while college teaching staff only received their individual letters in November 2004.

When we had begun the research, we had expected to repeat the distribution of questionnaires in Autumn 2004 so that we could measure the impact of the changes, but following this meeting we recognised that we had not yet reached the best time to survey students again.
What has been learnt from participation

Following the impact research, there has been a significant change in the way we have viewed our support for partnership students.

Previously, our service provision was based around how we would support students when they visited the University Learning Resource Centre and our initial research questions were partly to ascertain University staff readiness to deal with those students.

Our research findings led us to believe that many partnership students did not wish to visit the University LRC, but might be interested in using resources which could be accessed offcampus. Our emphasis shifted into seeing how we could make it easier for students to find out what resources were available to them, and how we should best support the college library staff to inform students of their rights.

We believe that participation in the research gave us the impetus to develop one area of our provision in a more systematic way than would otherwise have been likely. The results have led to significant changes as well as stimulating the discussion of issues at HEBP meetings. It has given us a very good starting point. However, there was a limit to how much change could be achieved in the time available, and so our challenge now is to continue with the work that has begun.

\section{References}

Quality Assurance Agency for Higher Education (200I) University of Teesside: Quality Audit Report. http://www.qaa.ac.uk/revreps/instrev/teesside/contents. htm

[Accessed 24 February 2005]

University of Teesside. Library \& Information Services. (2004) Mission, Values and Aims. http://www.tees.ac.uk/lis/whoweare/factsheets/fs0.pdf [Accessed 23 February 2005] 